\title{
Miranda
}

Revue pluridisciplinaire du monde anglophone /

Multidisciplinary peer-reviewed journal on the English-

speaking world

$12 \mid 2016$

Mapping gender. Old images ; new figures

\section{Walker Evans and Stephen Shore at the Rencontres de la Photographie d'Arles 2015}

Daniel Huber

\section{OpenEdition}

\section{Journals}

\section{Electronic version}

URL: http://journals.openedition.org/miranda/8411

DOI: $10.4000 /$ miranda.8411

ISSN: 2108-6559

Publisher

Université Toulouse - Jean Jaurès

\section{Electronic reference}

Daniel Huber, "Walker Evans and Stephen Shore at the Rencontres de la Photographie d'Arles 2015",

Miranda [Online], 12 | 2016, Online since 01 March 2016, connection on 16 February 2021. URL: http:// journals.openedition.org/miranda/8411 ; DOI: https://doi.org/10.4000/miranda.8411

This text was automatically generated on 16 February 2021.

\section{(c) (i) () $\Theta$}

Miranda is licensed under a Creative Commons Attribution-NonCommercial-NoDerivatives 4.0 International License. 


\title{
Walker Evans and Stephen Shore at the Rencontres de la Photographie d'Arles 2015
}

\author{
Daniel Huber
}

1 The "Rereading" section of the 2015 edition of Les Rencontres de la Photographie in Arles, 6 July-20 September 2015, treated visitors to two masters of American photography: Walker Evans ${ }^{1}$ (1903-1975) and Stephen Shore ${ }^{2}$ (born in 1947). They started systematically photographing their country four decades apart, in two different periods in the socio-cultural, political and economic history of the United States of America. Evans, after various projects including one on Victorian architecture in New England, photographed the people of the American South and vernacular architecture during the Depression years of the 1930s for the FSA (Farm Security Administration, originally the Resettlement Administration set up by Roosevelt as a measure of the New Deal). Shore, after a number of projects influenced by his trips to Warhol's Factory and by conceptual art of the late 1960s, started taking snapshots of a vernacular America that was completing its full conversion into a consumption society. Walker Evans' career saw the emergence of photography as a mass medium, spreading to every corner of culture through the printed press, until it became established as an independent art form in the late 1960s, collected by and exhibited in museums and galleries. This is when Shore took up his camera to roam the streets of his native New York and the Factory, and this is also the period that colour made its first appearances in art photography. Shore has repeatedly acknowledged in interviews the influence Evans' American Photographs (1938) had on him. He embraced the documentary style of photography he inherited and captured the changes at work in the visual arts, while his renewing of the photographic language has itself been instrumental in these changes. These two exhibitions, in the light of recent critical work by David Campany ${ }^{3}$ for both exhibitions, also provided the common ground for many of the themes and approaches addressed in other exhibitions in the main programme of the Rencontres in Arles: they provided for a unique experience of cohesion and diversity under the new direction of the Rencontres, headed up by Sam Stourdzé. 


\section{Text and image: the photo-essays of Walker Evans and their context}

2 The curators of Walker Evans, Anonymous, Jean-Paul Deridder, David Campany ${ }^{4}$ and Sam Stourdzé, have chosen for an innovative way of presenting Evans' photographs, on view at the Musée Départemental Arles Antique. Evans published in various magazines, such as Harper's Bazaar, Life, Vanity Fair, Vogue, Architectural Forum and, most importantly, Fortune, besides smaller avant-garde titles, since the 1920s. The exhibition focussed on Evans' print work that appeared mainly between the 1940s and 1960s in particular and has been essentially neglected until recently (Mora 1990: introduction; Campany 2014a: 9). This choice of focus was felicitous for at least two reasons. On the one hand, it drew attention to the relation between the image on the printed page and the accompanying text mostly written by Evans himself. On the other hand, it highlighted the process of selection and editing involved in the construction of a photo-essay as revealed by a comparison of the published images and the images from the same series that were not printed in magazines. The exhibition was arranged consistently with this innovative approach.

3 The exhibition space was a big room with a smaller walled space in the centre that visitors could walk about. These two spaces made for a clear and very effective thematic division. The inner space housed a representative selection of Evans' gelatin silver prints of photographs he had taken for his numerous series. One could thus see the photographs that did not appear in his photo-essay Labor Anonymous, although coming from the same series (see Sante 2001: 113 for such an image). Moreover, an impressive selection of his early portraits of ordinary citizens, independent from but reflective of his magazine work, was also presented in this inner space. One such example is Parked car, Small Town Main Street, 1932 that was published in American Photographs (Evans 1938: 28, plate 10) but not in a photo-essay. The outer exhibition space was completely devoted to the published magazine pages themselves: huge blowups of the full printed version of 12 of his photo-essays on the outer wall and some 20 
other contemporary magazine issues with his photo-essays and front pages in showcases.

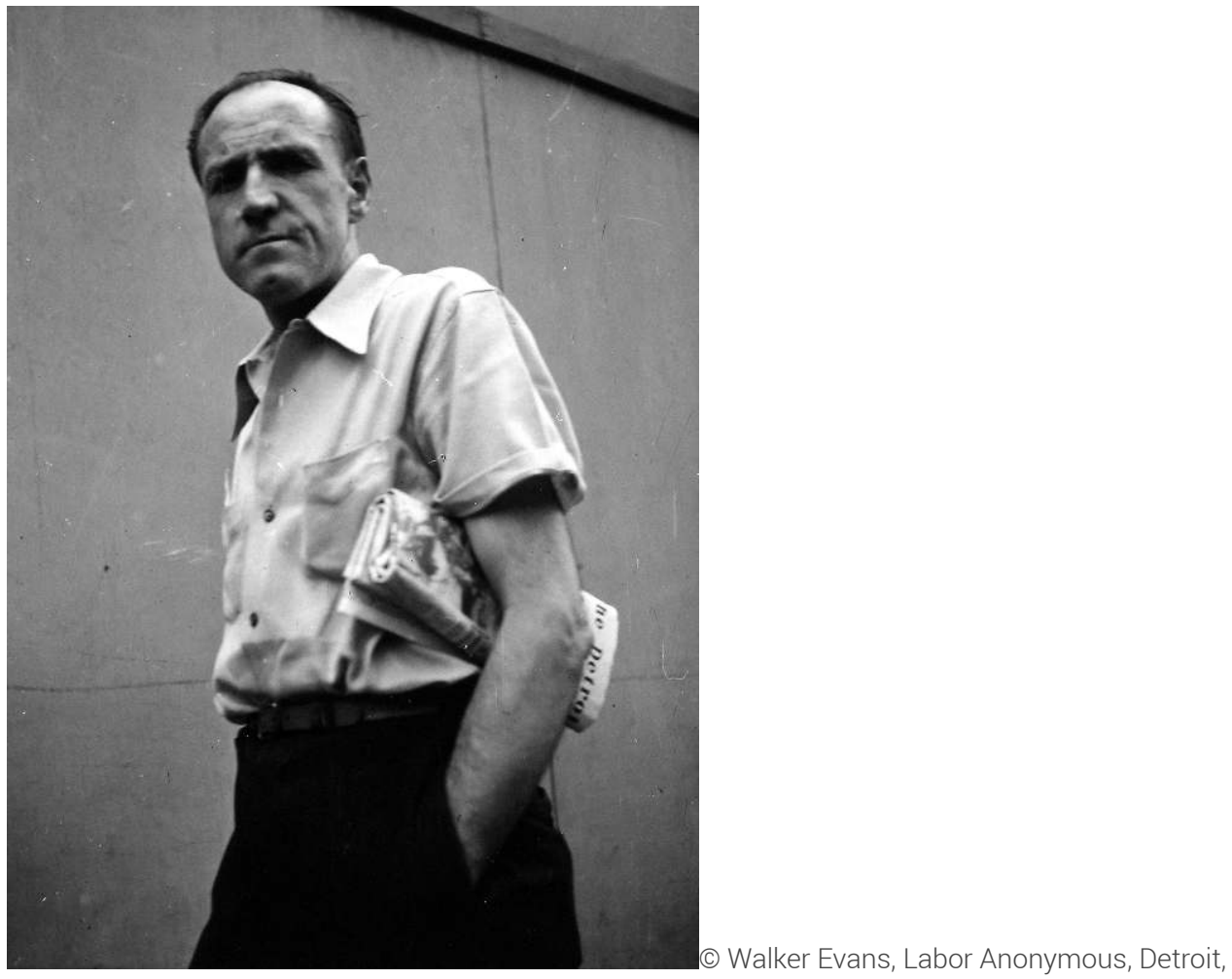

1946, for Fortune magazine. Courtesy of The Metropolitan Museum, New York.

Evans put great store by the layout of a popular magazine page and its contents: in the interaction between his images and his text on the printed page and, even more particularly, in his choice of subject matter. In addition, his magazine work may shed a different light on what he could have meant by the elusive term "documentary style" because if he meant a type of image use on the printed page rather than a type of image, then these portfolios are indeed documentary in style rather than documents (see Campany 2014a: 35 for discussion). A classic example of his method is his series Labor Anonymous. The photographs were taken on a Saturday afternoon in 1946 in the streets of Detroit for Fortune magazine, holding his medium format Rolleiflex camera at waist level ${ }^{5}$ as he took pictures of people walking past a featureless wall. He eventually selected 11 black and white images for the magazine, and laid them out in a way that the space of a twelfth image is taken up by the text he wrote himself ${ }^{6}$. The images, originally square $6 \times 6 "$, were cropped into vertical rectangular photographs. As Campany (2014a: 33) observes, the viewer has to be cautious with the interpretation of the sequence, though: the text mentioning a Saturday afternoon, the image placed top left showing a man looking straight into the lens with his hat in part covering his face and the final image showing a couple, are all features that belie simplistic interpretations as "observing and classifying unsuspecting specimens" on a typical working day. Since the images are of anonymous workers (all men and a couple) in an industrial area of Detroit, the essay is a bold counter-commentary on American society, its consumerist and celebrity-centred preferences, especially published in a magazine called Fortune. Thereby, Evans also questions the values and the role and responsibility of the mass media. It can be easily seen in general in his print work that where the mass media favoured celebrity culture, Evans portrayed anonymous citizens (as in 
Labor Anonymous, November 1946 or People and Places in Trouble, March 1961), where advertisements advocated consumerism, he captured enduring objects (as in Vintage Office Furniture, August 1953 or Beauties of the Common Tool, July 1955 and Before They Disappear, March 1957), where the media focussed on the now, he unveiled the persistence of the past in the present (as in Along the Right-of-Way, September 1950, The Wreckers, May 1951, The U.S. Depot, February 1953, and On the Waterfront, November 1960). All these essays cited above were published in Fortune, to which Evans contributed regularly between 1945 and 1965. Photographic Studies (1930) and Color Accidents (1958) appeared in specialized architecture magazines. His famous series Rapid Transit was published in the winter 1956 issue of i.e. The Cambridge Review, with a text written by James Agee in 1940 and possibly partly retouched by Evans on editing it posthumously for publication (cited in Campany 2014a: 71-72, note 156). ${ }^{7}$

With respect to the layout of the magazine pages, it is revealing of his editorial practice which essays were printed in colour, and which in black and white. He seems to have used colour prints for subjects where there was a dynamic context outside of the picture frame: either the idea of motion, as with railway travel, or transition from the past to the present, as with demolition sites and architectural structures left to decay. In connection with Color Accidents (1958), Sante (2001: 114) remarks that Evans discovered the use of colour in observing its transformation under the impact of the passage of time and the climate. Colour stands for his fascination for cultural decadence, in particular (Sante ibid.). Evans considered colour photography "vulgar" and valid only "[w]hen the point of a picture is precisely its vulgarity or its coloraccident through man's hand, not God's" (cited in Campany 2014a: 60). The portfolios that lent themselves to studying these ideas at the exhibition coincided with images where colour played a crucial role: for instance in his numerous series related to railway travel (Along the Right-of-Way, Before They Disappear, The U.S. Depot), vernacular architecture (American Masonry and The Wreckers), as well as in Color Accidents. In this context, it is to be noted that Evans did not approve of nostalgia at all and these photoessays did not lament the passage of time, he was "merely noting that 'not-newness' is what permits artistic access" since the "very latest of anything is impossible to contemplate" (Campany 2014a: 52). It is also important to note that it is only the narrative context which is dynamic: the images are all invariably motionless snapshots without blur or other indication of movement, of a single-building railway station with its turret or mansard, the insignia of railway companies painted on freight cars, remnants of an old stone wall partly in ruins, etc. However, socially sensitive portfolios presenting anonymous workers, passengers, jobless individuals in the isolation of their home and series referring to the unwavering permanence of objects such as common tools and office furniture are all consistently printed in black and white. Evans occasionally included a few black and white images even in the colour portfolios: for instance, to convey the permanence of the ticket office at an old railway station or to take a snapshot of three wreckers on the top of a building with their hammers about to fall. Change of state is thus represented in muted colours, while inertia and permanence in black and white.

6 Typography and texts played an important role in these photo-essays and they were well worth reading while looking at the photographs. Evans readily plays around with typography whenever the occasion arises. For example, in his photo-essay Along the Right-of-Way (September 1950, Fortune), he renders the repetitive "ting ting ting" of the 
warning-bell at the level crossing-"that heart-rending tinny decrescendo which is an early lesson in relativity of the senses"-in small capitals of diminishing font-size, echoing the perception of the passenger in the train as they pass the crossing. The font used in the title also mattered: the thin elongated block capital verticals resembling classical colonnades used for Imperial Washington, the curly calligraphy, suggestive of handwriting, chosen for Beauties of the Common Tool and the inevitable fading into the background colour of the paper, suggested by the heavy, relief-shadow serif outline font, for Vintage Office Furniture, all matched the aesthetics of the subject matters. The choice of words and his style is also integral to these essays. Although Sante (2001: 112) claims that the text accompanying Labor Anonymous in Fortune comprises a list of job titles Evans found in the jobs section of local newspapers, the text is in fact about the American worker whose "blood flows from many sources", whose "features tend now toward the peasant now toward the patrician", who "would seem to have a solid degree of self-possession" and who "are citizens of a victorious and powerful nation". Evans concludes that these photographs demonstrate the impossibility of lumping them all together under the editorial catchword "labour": "these laborers can no doubt laugh that one off." Thereby his photographs invite the reader to try to understand how modern urban life brings us into contact with other people, often for a brief moment, and challenges us to consider what we know from a photograph of somebody in such a fleeting image. Can we make a judgement based on a photograph, what sense does a photographic document make, and how do we read it (Campany 2014a: 33)?

Obviously, there would be a lot of cultural-historical commentary to be made on the contents of his texts as well as his style. His style, which he honed especially during his stay at Time magazine between 1943-1945 as contributing editor (Campany 2014a: 28), is not devoid of mannerisms according to Chevrier (2010: 71), "rich with rhetorical flourishes", "peppered with vernacular touches, literary quotations, obscure historical references, pithy facts and adjectives of baroque splendour" in Campany's opinion (2014a: 38), "limpid, almost dry, in the style of Truman Capote" according to Mora (1990: introduction). In the text accompanying American Masonry (April 1965, Fortune Magazine, pp. 150-153), Evans writes that

Americans don't see much real stonework, stone building that can be felt. This makes the simple, beautiful examples which we do come upon, mostly in the East, all the more satisfying. [...] Hence the raptures of the eye-starved U.S. tourist arriving before such European poems in stone as Chartres, or Paestum, or even a simple cobble barn set in the English countryside, say in Norfolk.

These are cultural historically important remarks on American society and selfperception that provide the colours of the backdrop to his photographs. Then he goes on to say that American masonry is

[h]umbler, but sound, truly functional, and - pure. [...] An ordinary farm field wall has to be so built that the heaving of the ground in hard winter frost won't cause buckling. When you see unlevel walls and pieces fallen out, that is jerry-built stuff.

Who will not have Robert Frost's poem Mending Wall (published in 1914) evoked by these lines? In other of his texts he makes reference to Mark Twain or Faulkner. These texts were thus small fragments to the delight of visitors with literary sensibilities. The only major shortcoming in the presentation of these photo-essays at the exhibition was that there were no French translations or even summaries of Evans' texts in the exhibition space. This was all the more a pity since these texts were well worth reading 
for their own sake but they could be a challenge for visitors with only a limited knowledge of English.

A personal favourite is his photo-essay Before They Disappear where all the points presented above can be profitably studied. It dates from Evans' work of the 1950s when he concentrated, in Campany's words (2014a: 45), on "minor charms endangered by corporate sprawl and modern design". The idea was first outlined in a memo dated 10 March 1954 (Campany 2014a: 48). It eventually became a five-page portfolio published three years later, in the March 1957 issue of Fortune. Since the title refers, albeit enigmatically, without naming the subject, to disappearance, it is consistent with his editorial practice that the series is printed in colour. The objects photographed are the insignia, originally designed in red, white or black in the $19^{\text {th }}$ century and gradually redesigned in the 1950s, of the historic railway companies such as the Santa Fe, the Atlantic Coast Line, the Northern Pacific, the Union Pacific Railroad, etc. Evans provides this information on design history in the captions themselves. It is evident that a lot of thought went into the conception of the structure of the portfolio. The 13 photographs are close-ups of these signs against the rust-hued, brownish backdrop of the freight car sides on which they were painted: abstract images in superb if muted colours. The title and the text below, signed Walker Evans, take up the space of one photograph each on the first page in the company of 4 images: one image isolated underneath the title and the text, in the same column to the left, and 3 images arranged in the right-hand column. This is the title-abstract-introduction page. Then follows the elaboration of the "plot": a double-page layout with 6 larger images, 2 of which straddling the page-break: all of these photographs are shot from a similar angle from below. The rhythm decelerates on the following page with 2 larger photographs that also share the same aesthetic aspect because the insignia are written in a hand slanting now to the left now to the right. The final page is a coda of a single full-page photograph: the insignia of the Atlantic Coast Line overshadowed by a mast. He writes in the first of a four-paragraph text: "We once knew them all by heart. They were with us like the weather, like the backs of books we collected, and like the streets we walked in." In the second he refers to (his) selecting the images in order for these insignia to evoke "the very sounds of railroading - the iron whines, the steely screeches and the attenuated nocturnal moans of steam transportation." Tightly scripted, personal, evocative: editorial. He then goes on to take note of the changes in signature (reproducing them typographically in the running text!), finally concluding, in a somewhat mannerist style, that when these signs have gone, "then will a whole world of cherished association have been destroyed. Impiety could go no further." The text and the layout of the photographs interact in important ways. As already mentioned, the text takes up the space of exactly one image. The isolated image in the column below the title and the text on the first page is a photograph of the aesthetics of the new design the text refers to as "exceedingly distinguished lettering" designed with " $\mathrm{T}$ square poised". The anti-hero of the essay is thus presented in isolation from the rest of the portfolio. The crop of the images, never quite symmetrical or parallel with the frame, underlines this sense of urgency in recording these fleeting graphic shapes the text describes. The final page with its overshadowed insignia responds to his warning at the end of his text: the original designs are bound to disappear. Evans' photo-essays illustrate brilliantly how text and image must be considered together on a magazine page. 
11 His method of publishing his photographs with his own texts is the result of aspects of his personal life and his time. Evans originally dreamt of a career in literature, wanted to translate Baudelaire, read avidly in English and French-which is why he spent time in Paris, in 1926-1927, at the Sorbonne and at the well-known Shakespeare \& Co. bookshop (Campany 2014a: 10-11). He wanted to become a professional writer later on, but he did not succeed and found writing difficult. Nevertheless, providing photographs for magazines and writing most of the texts accompanying his images, he successfully combined writing with photography. He also produced "The Reappearance of Photography", a review article of a number of photographic books, published in the Hound and Horn in 1931 (see Campany 2014a: 17-20; 213-214, for an analysis and reprint, respectively) as well as reviews in Time. To further illustrate his interest in images accompanying texts, Evans made the photograph sequences for The Bridge by Hart Crane (1930), The Crime of Cuba by Carleton Beals (1933) and Let us now Praise Famous Men by James Agee (1941), among others (Campany 2014a). Many of these works were presented in the showcases at the exhibition. One also has to remember that Evans worked at a time where it was difficult to make a living as an "art photographer", in the absence of an art market as we know it today. Finally, it was more than lucky that he could enjoy virtually unlimited artistic control over his assignments at Fortune.

\section{Shore: ${ }^{8}$ changes in colour in the documentary style}

The exhibition devoted to the career of Stephen Shore, on view at the Espace Van Gogh under the curatorship of Marta Dahó, followed a different but equally effective and stimulating organization on two floors of the exhibition space. A chronological overview was perfectly adapted to the most comprehensive exhibition to date and the first European retrospective of one of the pioneers of American colour photography. ${ }^{9}$ This sequential presentation was also felicitous because it highlighted the linearity of the path Shore has taken in incessantly renewing his approach and language. While Shore admits to the influence of Evans, Ed Ruscha and, to some extent, of Andy Warhol, he has himself been a major influence on generations of photographers and his work is crucial to an understanding of the contemporary photography scene and some of the practices that dominate it. Shore has also been active in the theory of photography ${ }^{10}$ : he has been director of the Photography Department at Bard College, New York State, since 1982, and is author of The Nature of Photographs (1998) ${ }^{11}$. His photographic and theoretical work contribute to an appreciation of the dynamics of a period where the relations between visual arts and photography were much more intense and prolific than historiography would make us believe (although recent work by David Campany has tried to correct this bias, as Dahó 2014: 9-11 observes).

The exhibition space was perfectly adapted to the chronological presentation of Shore's work. An introductory room on the ground floor housed a selection of his early black and white photographs from his youth as well as from his period at Warhol's Factory between 1965-1967. Lange (2008: 42) recalls the episode when Shore, aged 14, contacted Edward Steichen, the director of the Museum of Modern Art at the time, and possibly it was a sign of Steichen's clear-sightedness that three of his photographs entered the collection in 1962. Lange (2008: 43) evokes that between 1965 and 1967 Shore was a regular at the Factory where he took pictures of Warhol, his friends and his work, and she goes on to conclude (2008: 45) that his presence at the Factory is one of the distant 
but discerning observer that Shore will eventually transform into a visual attitude with respect to his subject. It is also at the Factory that he discovers the taste of consumption culture and the techniques of mass production (Lange 2008: 47). She points out (ibid.) that it is remarkable that Shore did not become part of the pop art movement and chose photography instead, which was not at all part of the art world of the late 1960s.

This introductory room also presented the compositions that emerged from his experiments in "serial imagery" and conceptual art that he discovered in Ed Ruscha's work in 1968, in particular in his Every Building on the Sunset Strip (1966), and in Serial Imagery (1968) by John Coplans: Shore started producing systematic, analytical series in a medium, photography, that was not the predilection of conceptual artists for selfexpression at the time (although many of them did use a camera as a point of departure for exploring their ideas). In July 22, 1969/July 23, 1969 he took a picture of his friend Michael Marsh every 30 minutes for 24 hours, in Circle No. 1 (1969) he took a series of pictures of Marsh facing him looking at the 8 directions of the compass, with a desert as background. It is in connection with these projects that Shore refers to the need to find the "exact moment" (say every 30 minutes) rather that the "right (or decisive) moment" of Henri Cartier-Bresson. For instance, in Circle No. 1, he did not intend to give snapshot portraits or render a romantic vision of the desert: he wanted to give a simple geographic context to his subject, thereby turning the camera into an analytic tool. The images in this first room, some shown for the first time in public, helped visitors to understand how his major series of the 1970s emerged and how they fit in his career. Lange (2008: 52) adds that his following smaller projects, for the first time in colour, confirmed his interest in amateur photography and its aesthetics, his fascination for the creative potential of technical constraints (such as using a Mick-o-matic toy camera).

The next room presented a generous selection from Shore's two great series from the 1970s, all in colour: 96 photographs from American Surfaces (1972-1973) ${ }^{12}$ and 56 photographs from Uncommon Places (1973-1981) ${ }^{13}$. A very nice idea was to present American Surfaces similarly to the way they were first shown in autumn 1972 at the Light Gallery in New York: three rows of relatively small, 12,7x19,1 cm, untitled images printed on $20,3 \times 25,4 \mathrm{~cm}$ sheets ${ }^{14}$. The change in style of Shore's photography for Uncommon Places was also brought out by hanging the much larger images, 43,2x55,2 $\mathrm{cm}$, individually. Also, his 1971 series, Greetings from Amarillo-Tall in Texas, a series of postcards with unnamed and unimportant buildings of Amarillo, and A Road Trip Journal (1973) were presented in table showcases along the midsection of the room. It is precisely these two experiments of the early 1970s that led him to the development of the aesthetics of what he calls "snapshotness" in American Surfaces (Dahó 2014: 15-16).

Shore incessantly concentrated on what role the camera plays in transforming the world into images and what the conditions and effects are of this mediation (cf. his book The Nature of Photographs). His early photographs show the impact of serial thinking, conceptual art and variation. American Surfaces originated as his "intimate visual diary", as he described them in an interview with Michael Fried (Lange et al. 2008: 11), that he kept during his travels across the United States. But one looks in vain for major monuments in the various locations Shore visited: the photographs are snapshots of people he met, cafés and restaurants he sat in for a meal and the meals he had, the beds he slept in, the motel rooms he stayed at, public facilities he accessed, the 
paintings and pictures on the wall and decoration in general, the TV sets he turned on to watch, store fronts and the architecture of the houses he saw and views of crossroads and streets he walked in: landscapes of the commonplace, the banal, the presumed unaesthetic-all in (their true) colours, and most interior scenes shot with a flash. They are testimonies to what could well be perceived as the perfect American normality of the time (Dahó 2014: 15). His method of working at this time is a continuation of his earlier conceptual series. According to Lange (2008: 59), Shore succeeded in creating the coexistence of the seriousness of Evans's American Photographs, the vividness of pop art and the harsh perspective of conceptual art in American Surfaces. He took these photographs without proper framing or focus, without heed to lighting, and including sections that most tourists would have left out of the composition such as the flaking railing along U.S. 89 in Arizona.

\section{STEPHEN SHORE}

Normal, Illinois, July 1972

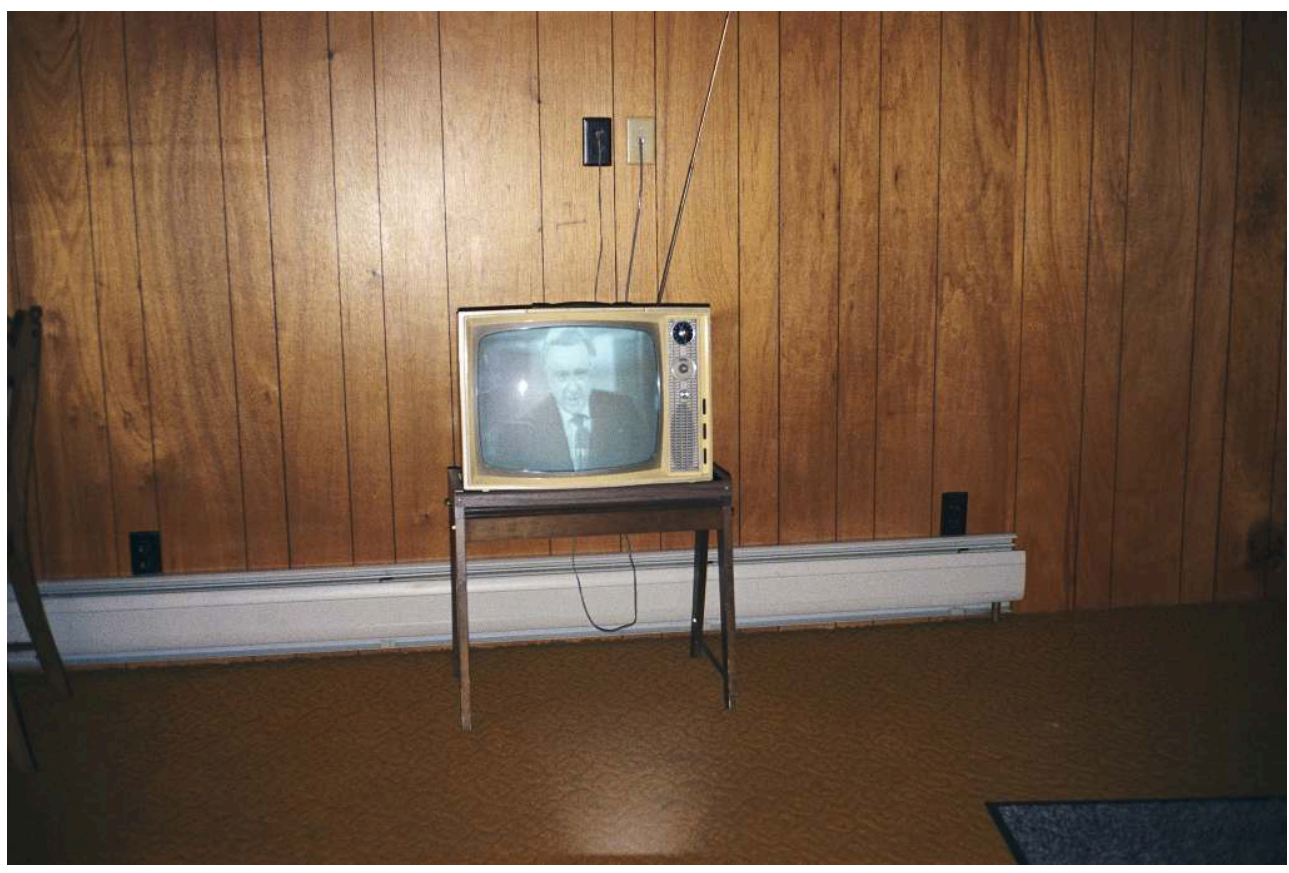

1972

Chromogenic color print

$5 \times 71 / 2$ inches

$(12.7 \times 19.1 \mathrm{~cm})$

SS 008

(C) Stephen Shore, courtesy 303 Gallery, New York 
STEPHEN SHORE

Clovis, New Mexico, June 1972

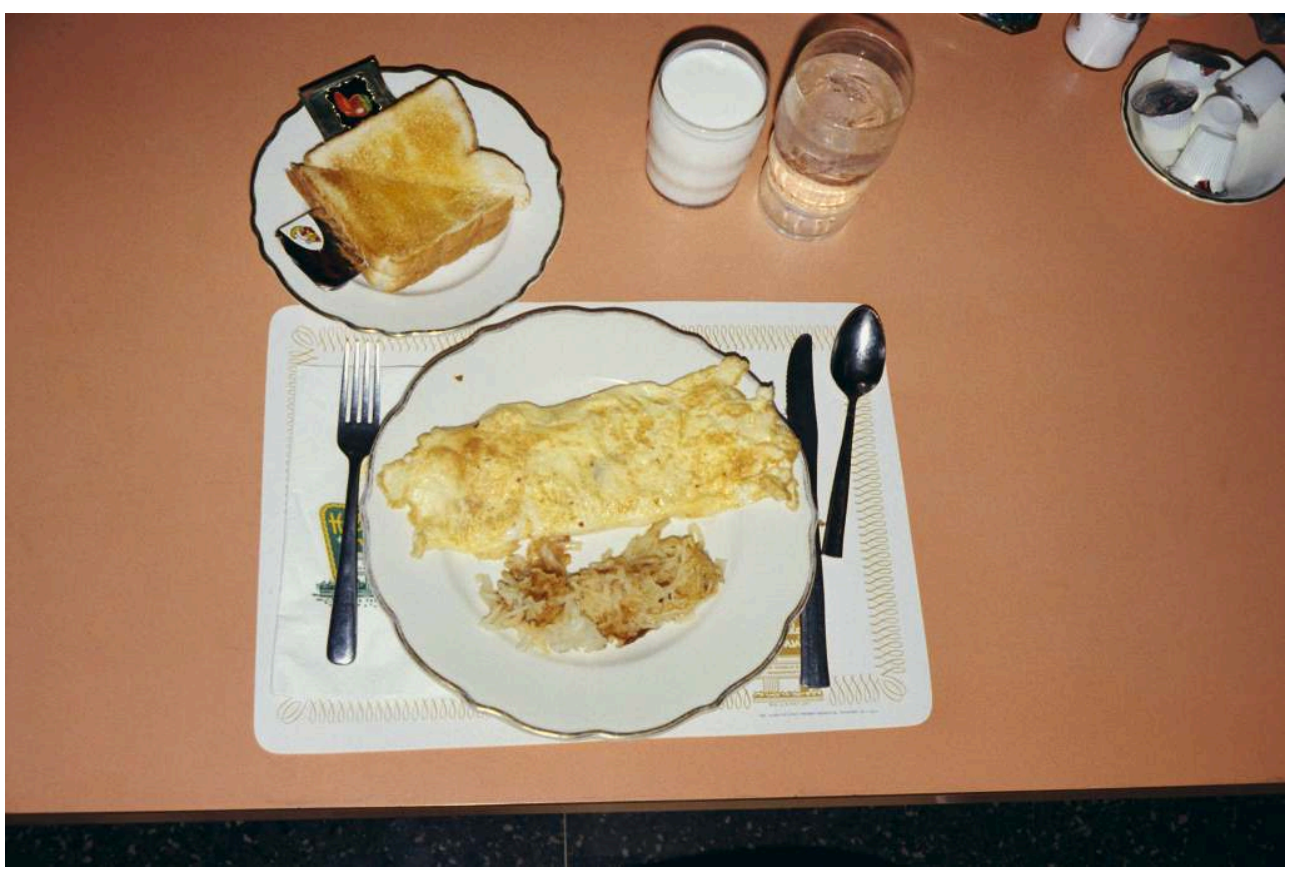

1972

Chromogenic color print

$5 \times 71 / 2$ inches

$(12.7 \times 19.1 \mathrm{~cm})$

SS 343

(c) Stephen Shore, courtesy 303 Gallery, New York 
STEPHEN SHORE

U.S. 89, Arizona, June 1972

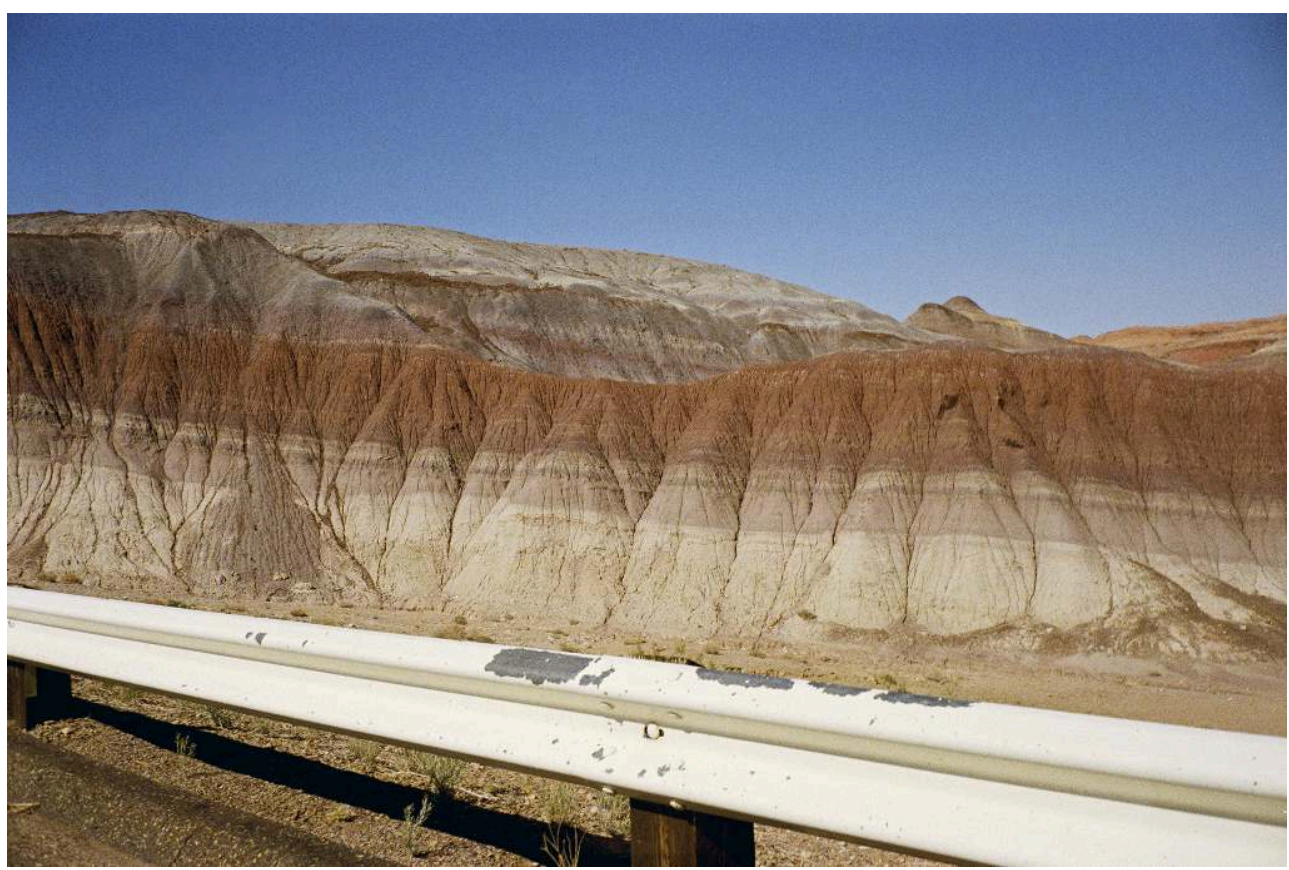

1972

CHROMOgENIC COLOR PRINT

$5 \times 71 / 2$ INCHES

(12.7 X $19.1 \mathrm{~cm})$

ss 384

(C) STEPHEN SHORE, COURTESY 303 GALLERY, NEW YORK

Some images of the two series are not devoid of humour, such as the image from American Surfaces where two men are standing still, arms down, legs slightly apart, looking down a street with their back to the viewer (and the camera), underneath a sign that says "STAND". Or there is the photograph of Horseshoe Bend, Motel, Lowell, Wyoming, July 16, 1973, a snapshot after rain from Uncommon Places where there is a rainbow overarching the name of the motel, Horseshoe Bend. Of course, the title of this series is also a pun. Dahó (2014: 10) points out, however, that one has to be aware of the changing nature of interpretations and her warning applies to Uncommon Places in particular: the title was indeed intended as a pun on "commonplace" but it is only now, in view of the social and economic changes since the 1970s, that the places Shore photographed have truly become commonplace.

To make the photographs for Uncommon Places, Shore used a larger format camera, first a 4x5" Crown Graphic in 1973 and then from 1974 a 8x10" Deardorff camera. As Marta Dahó explains (2014: 17), the technical constraints of such a camera-it necessitated a tripod and longer exposure times and being a folding camera it is not at all discretemade for more complex compositions and the real challenge he had set for himself was still to imitate the snapshotness of American Surfaces. The issue of the viewpoint became primordial for this project. He managed to reconcile his aims and the technical constraints by focussing on the essential: roads and vernacular architecture, making creative use of every aspect of the urban and suburban geometry at his disposal such as lampposts, pylons and wires. The sharp fine details in these large format photographs require considerable attention from the viewer. In his essay on Shore's photograph 
Holden Street, North Adams, Massachusetts, July 13, 1974, Joel Sternfeld (Lange et al. 2008: 119) points out that the large format camera was a choice against the popularity of small and medium format camera that Robert Frank, Lee Friedlander, Garry Winogrand and Diane Arbus used masterly in the 1960s, but at the same time, shore used the large format also differently from the way the f64 group used it on the West Coast because he used colour film. His images are completely devoid of sentimentality, let alone any judgement on his part, but is very rich in emotional content: it is pure attention, attention to the impressions things make on him. Sternfeld (op.cit.: 120) points out that in American Surfaces Shore's focus was on himself in his environment and how he moved on towards a feeling of being in agreement with his environment in Uncommon Places and his later work. Indeed, in Uncommon Places the exteriors do make use of the urban environment: the colours of the cars (far more vivid than most (European) street scenes would offer nowadays in the mid-2010s), the reds of the bricks, the arrangement of crossroads and traffic lights. Shore himself summarizes his use of colour in the Postface of the book edition of Uncommon Places (1982: 63):

Color film is wonderful because it shows not only the intensity but the color of

light. There is so much variation in light between noon one day and the next,

between ten in the morning and two in the afternoon.

\section{STEPHEN SHORE}

Holden Street, North Adams, Massachusetts, July 13, 1974

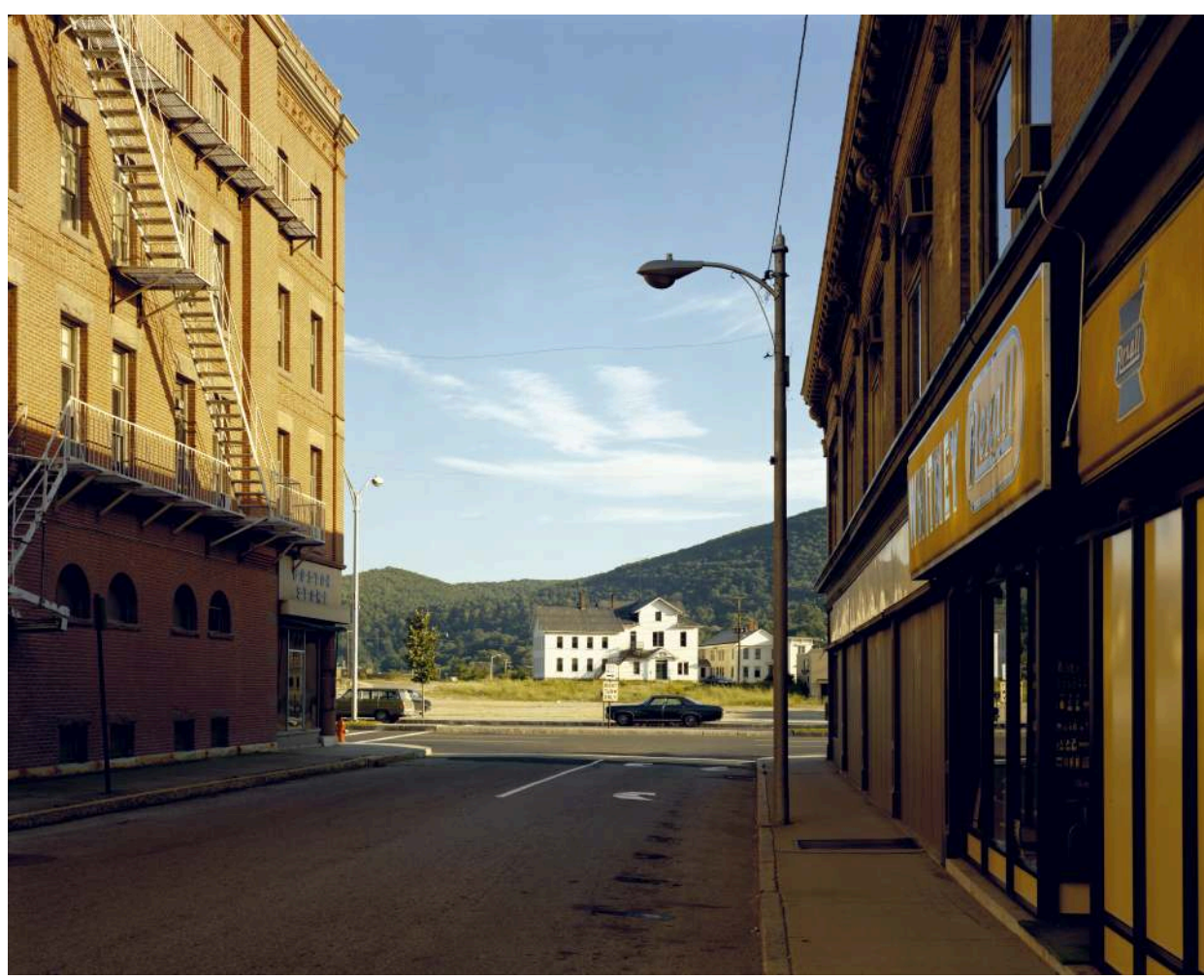

1974

CHROMOgENIC COLOR PRINT

$17 \times 213 / 4$ INCHES (43.2 X 55.2 CM) IMAgE SIZE

20 x 24 INCHES (50.8 x $61 \mathrm{CM})$ PAPER SIZE

ss 266

(c) STEPHEN SHORE, COURTESY 303 GALLERY, NEW YORK 
Salvesen (2010: 48) points out that in the landmark 1975 exhibition New Topographics at the George Eastman House, Rochester, New York State, a selection of 20 pictures of Shore's were the only colour contribution (of which 5 photographs were also shown in Arles). With respect to the title of the series, Uncommon Places, it might not be a coincident that "American" is absent: Shore apparently aimed at a photographic description that had vaster validity. Indeed, it is culturally interesting to note that some of the photographs of this series were shot in Canada, in Ontario and in Saskatchewan in August 1974: these scenes fade well into the continuum of the North American urban landscape.

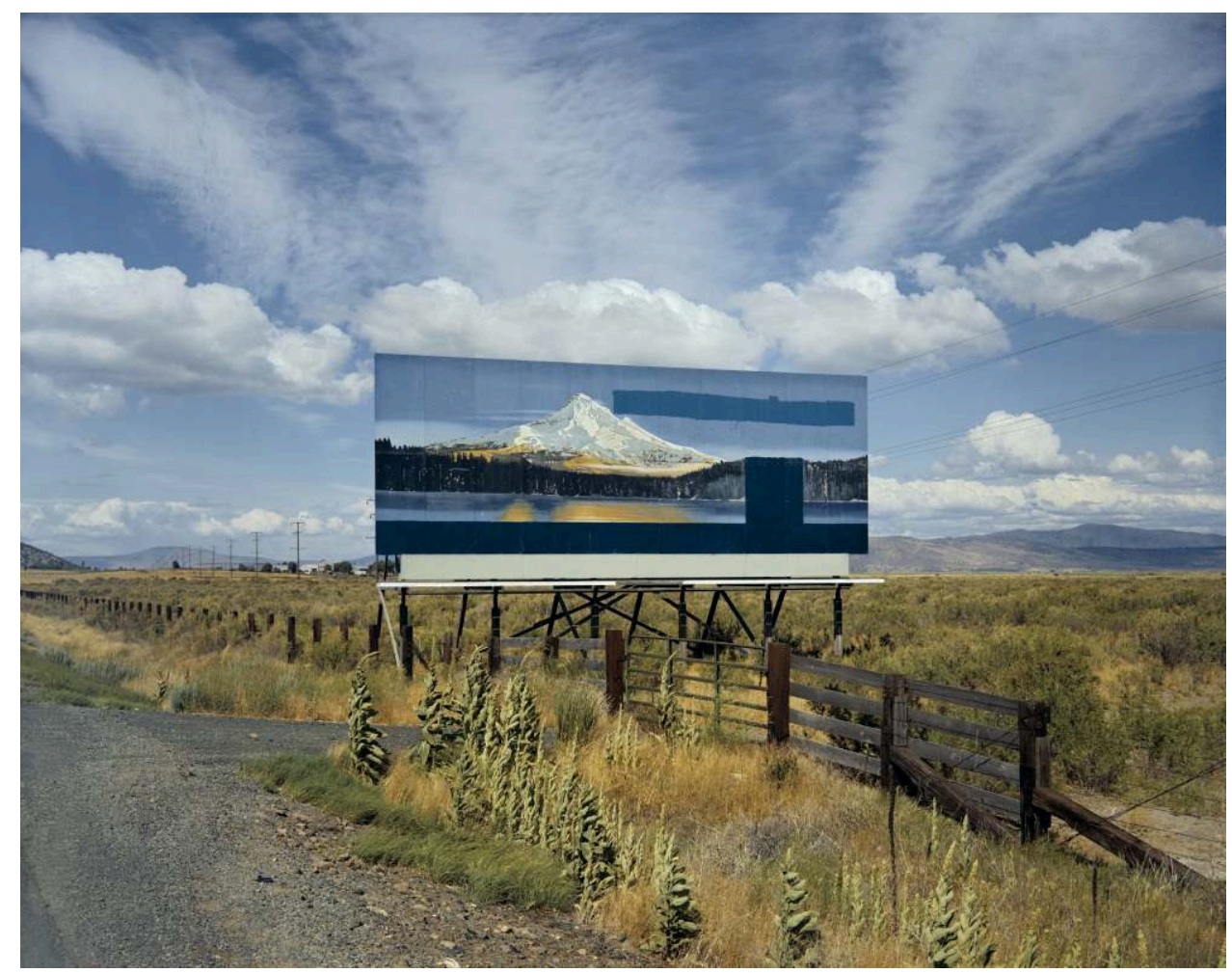

\section{CHROMOgENIC COLOR PRINT}

$17 \times 213 / 4$ INCHES (43.2 X 55.2 CM) IMAgE SIZE

$20 \times 24$ INCHES (50.8 x 61 CM) PAPER SIZE

Ss 065

(C) STEPHEN SHORE, COURTESY 303 GALLERY, NEW YORK

The final room on the ground floor housed Landscapes, which is the culmination of many of his ideas addressed during the previous decades. These images, taken in Texas and in Sutherland, Scotland, throughout the 1980s answer the question how to organize the image in the absence of anything salient or specifically human in the landscape, how to give the impression of space where there are no visual cues to help the viewer (Dahó 2014: 18-19). The viewer is drawn into these images of a hypnotic luminosity and the eyes will inevitably run along every little detail of the images: because there is nothing else to distract the attention. 


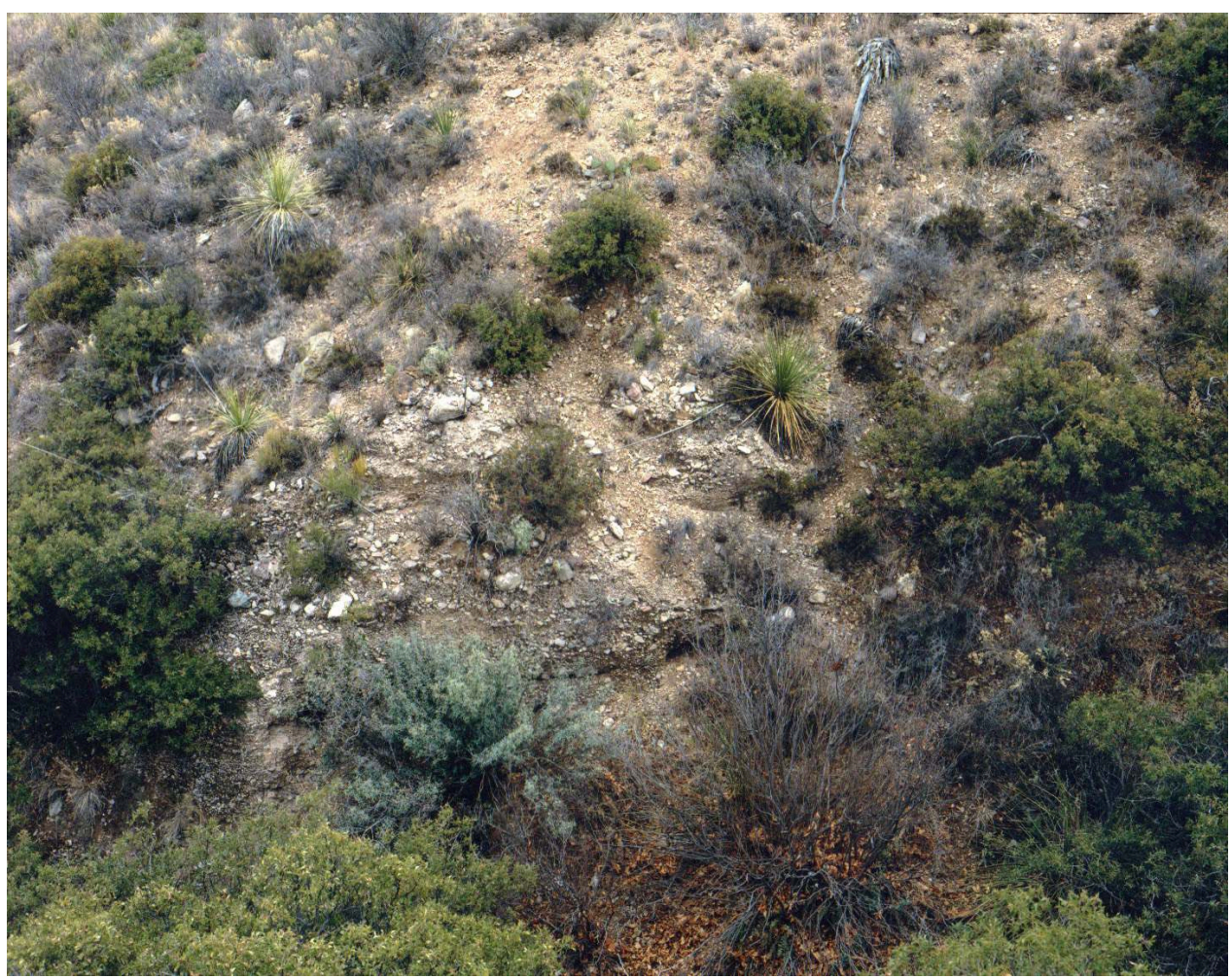

1987

CHROMOgENIC COLOR PRINT

$36 \times 45$ INCHES $(91.4 \times 114.3 \mathrm{CM})$

$40 \times 49$ INCHES (101.6 X 124.5 CM) PAPER SIZE

SS 1324

(c) STEPHEN SHORE, COURTESY 303 GALLERY, NEW YORK

The first floor rooms showed his series Essex County (1992-1995), Archeology (1994), New York City (2000-2002), all in black and white, as well as Ukraine (2012-2013) and Winslow (2013), in colour. After having photographed in colour for about two decades, Shore set himself the task of working again in black and white exclusively, for the following decade. As Dahó (2014: 20) points out, this is surprising by its deliberate planning and coming from someone who had personally contributed to the acceptance of the use of colour in art photography. In Essex County (1992-1995, published in 2002) there are no faraway horizons or their absence as in Landscapes, there is actually no landscape here. It is made up of a series of photographs of tree barks and stones. These latter, as Shore himself points it out in a short text exceptionally accompanying his images, are anorthosites, an igneous rock that makes up the crust of the Earth and is also present on the Moon: this detail is not negligible inasmuch as it uncovers the conceptual core that Shore has constructed throughout his career around the question of surfaces. His next series, Archeology (1994), was taken at excavation sites at Tell Hatzor and Ashkelon in Israel. But unlike an archaeological photographer or a tourist would have done, Shore chose to take photographs of how the objects make it to the surface anew, of the look of the site itself with its ground plans of ruins and spades and buckets, of the random arrangement of the objects in crates and in cardboard boxes before dispatch to the museum, everyday household objects like jugs, jars, plates, shards: images of the everyday banality of an excavation site. In these two series, his visual and discursive 
reflection on surfaces integrates scale as a new element, scale in space in Essex County and scale in time as well in Archeology.

\section{STEPHEN SHORE}

Hatzor, Israel, 1994

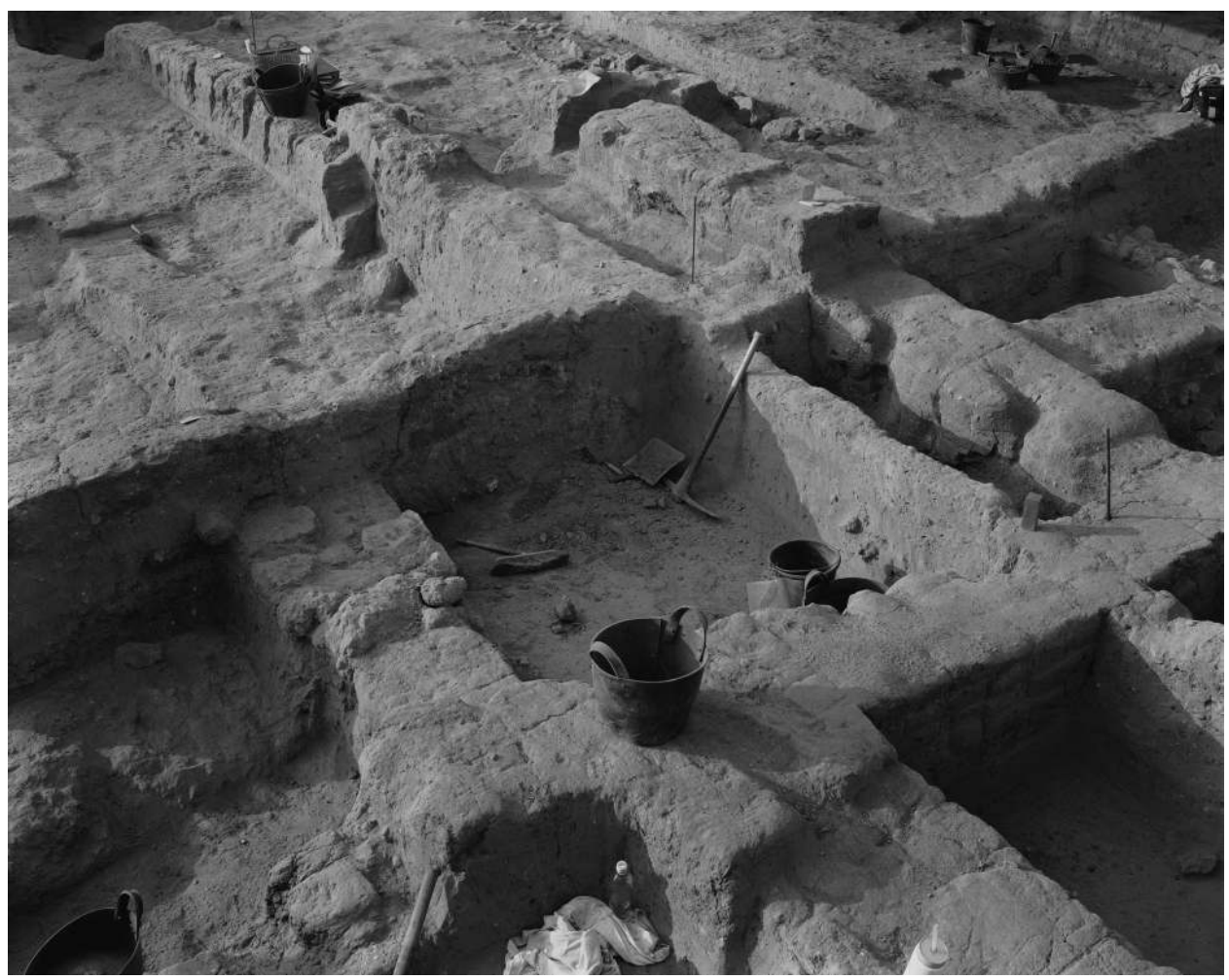

1994

BLACK AND WHITE INKJET PRINT

$30 \times 38$ INCHES (76.2 $\times 96.5 \mathrm{CM})$

$36 \times 45$ INCHES (91.4 X 114 CM) PAPER SIZE

SS 1312

(C) STEPHEN SHORE, COURTESY 303 GALLERY, NEW YORK

In New York City (2000-2002) he revisits street photography, paying tribute to Walker Evans and Garry Winogrand, but with a large format camera and in black and white: a real challenge. The prints are huge, 94x241,3 cm: every single detail can be observed, and there is a lot. His more recent project, Ukraine (2012-2013), led Shore to understand the importance of his personal history for his work since the series is directly connected to his Jewish origins: he went back to the area his paternal grandfather left in the 1890s, to photograph poor and old survivors of the Holocaust. The challenge was how to create an image that is not an illustration, and how to attain that the image rests on a strong emotion without being obvious. The result is a series of interiors, dust-covered and time-worn old books in Hebrew, the simple meals they prepare and the environment of their homes-deeply respectful, tender and personal images, in colour again. A display showed thumbnails of his iPhoto Books series, regularly published for a number of years now, making it clear that Shore has not shunned further technological possibilities for exploring photography. The exhibition ended with his most recent series where different elements of different ages create multiple layers of time: Winslow, Arizona (2013), on the Road 66 where Robert Frank also took pictures for The Americans (Frank 1958: 79). 


\section{STEPHEN SHORE}

Winslow, Arizona, September 19, 2013

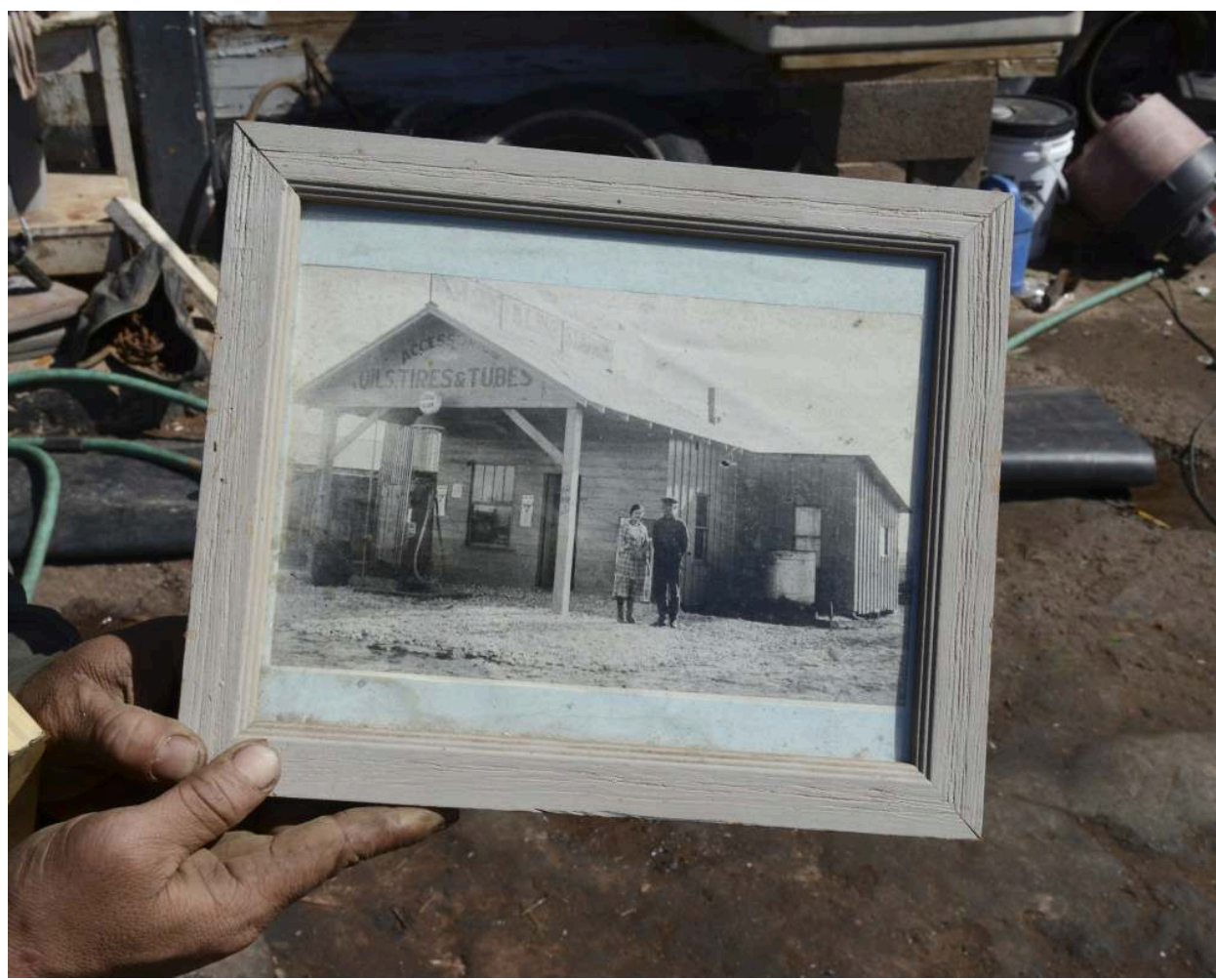

2013

CHROMOgENIC COLOR PRINT

$16 \times 20$ INCHES (40.6 X 50.8 cM)

$20 \times 24$ INCHES (50.8 x 61 CM) PAPER SIZE

ss 1216

(C) STEPHEN SHORE, COURTESY 303 GALLERY, NEW YORK

\section{Concluding remarks}

These exhibitions have shown a United States as these two giants of American photography saw the look of the nation, and together have spanned more than 80 years of the history of the urban scene in the US as represented in photography. These decades saw photography grow into a mass medium and then grow into an independent visual art form, precisely as a consequence, in great part, of the photographic work of Walker Evans and Stephen Shore. It made visiting the two exhibitions a unique and enriching experience: there were numerous points of contact and cross-references between them and the other exhibitions in Arles. The exhibitions and the catalogues that accompany them will most certainly remain a point of renewed reference for still further generations of photographers to come. The Walker Evans show did a very remarkable job of breaking away from privileging "the museum wall over the page" as Campany puts it (2014a: 66), which had been common practice since the 1971 Evans retrospective at MoMA curated by John Szarkowski. This update had to be presented in the museum space. The Stephen Shore show spanned all the stages of a remarkable, ever-evolving career devoted to the visual representation of the surfaces surrounding human existence. 
The exhibitions are on tour in Europe: after a first exhibition in Madrid in late 2014, Stephen Shore will move to Torino between September and December 2015, to Berlin between January and April 2016 and finally to Amsterdam between July and September 2016; The Magazine Work of Walker Evans was first presented in France recently at the Pôle Image, Haute-Normandie, in Rouen between 13 March and 9 May $2015^{15}$ and was earlier shown during the Krakow Photomonth, 15 May-15 June 2014 and subsequently at the FotoMuseum Provincie Antwerpen between 27 June and 11 November 2014.

\section{BIBLIOGRAPHY}

Adrien, Muriel, “Saul Leiter : Rétrospectives 1950-1960”, Miranda [Online], 11 | 2015, Online since 29 July 2015, connection on 22 September 2015. URL : http://miranda.revues.org/7488 Arles 2015 Les rencontres de la photographie. 2015. Arles: Actes Sud.

Campany, David (ed.). Walker Evans, The Magazine Work. Steidl: Göttingen, 2014a. ${ }^{16}$

Campany, David. Road Trips. Voyages photographiques à travers l'Amérique [original English title: The Open Road, Photography and the American Road Trip]. Paris: Editions Textuel, 2014b.

Chevrier, Jean-François. "Note sur la première contribution d'Evans à Fortune". In Walker Evans dans le temps et dans l'histoire. Ed. Jean-François Chevrier. Paris: L'Arachnéen, 2010. 62-85.

Dahó, Marta. “Stephen Shore. Les paradoxes de la transparence”. In Stephen Shore: Survey. Fundación MAPFRE. Editions Xavier Barral, 2014. 9-21.

Evans, Walker. American Photographs. With an essay by Lincoln Kirstein. New York: The Museum of Modern Art, 1938.

Frank, Robert. Les Américains. Lausanne: Delpire Editeur, 1958 (1997).

Lange, Christy. 2008. "Rien n'est délaissé” (original English title: "Nothing overlooked"). In Stephen Shore. Ed. Lange et al. Paris: Phaidon Press Limited, 2008. 39-112.

Lange, Christy, Michael Fried, and Joel Sternfeld. Stephen Shore [traduction française]. Paris: Phaidon Press Limited, 2008.

Mora, Gilles (introduction by). Walker Evans. Collection Photo Poche. Paris: Centre National de la Photographie, 1990.

Edition spéciale “Rencontres d'Arles 2015”. Le Point. Free copy.

Salvesen, Britt. "New Topographics”. In New Topographics. Center for Creative Photography, University of Arizona, George Eastman House International Museum of Photography and Film, Steidl. Göttingen: Steidl Publishers, 2010.

Shore, Stephen. Uncommon Places. New York: Aperture, Inc., 1982.

Shore, Stephen. Surfaces américaines [traduction française]. Paris: Phaidon Press Limited, 2005.

Sante, Luc. Walker Evans. Paris: Phaidon Press Limited, 2001. 
Sternfeld, Joel. 2008. "Holden Street, North Adams, Massachusetts, July 13, 1974". In Stephen Shore. Ed. Lange, et al. Paris: Phaidon Press Limited, 2008. 113-121.

Stephen Shore: Survey. ${ }^{17}$ Fundación MAPFRE. Editions Xavier Barral, 2014. The work, functioning as the exhibition catalogue, includes an essay by Marta Dahó, further texts by Horacio Fernández and Sandra S. Phillips and an interview between David Campany and Stephen Shore.

\section{NOTES}

1. Special thanks to Claudine Colin and Marika Bekier, in charge of communications with Rencontres d'Arles, for providing the digital images for this review.

2. Special thanks to Renee Delosh and Robbie McDonald, of 303 Gallery, New York, for providing the digital images for this review.

3. http://aperture.org/blog/walker-evans-written-word/

4. http://aperture.org/shop/walker-evans-masters-of-photography

5. He had already practised this method of taking images for the 1941 portfolio In Bridgeport's War Factories, (Campany 2014a: 54).

6. According to Chevrier (2010: 71), he wrote the text himself "without doubt, at least partly". See Campany (2014a: 69, note 84) on the history of drafts for this piece.

7. For a comprehensive list of Evans' print work, see www.artnet.com, http://www.artnet.com/ usernet/awc/awc_history_view.asp?aid=424171103\&info_type_id=5 or http:// www.fulltable.com/vts/f/fortune/menug.htm; for their presentation, see Campany 2014a.

8. http://www.stephenshore.net/

9. Shore was not the first to use colour film for artistic purposes: Saul Leiter preceded even Eggleston in this approach, see Adrien 2015.

10. Evans was also involved in teaching: after retirement from Fortune on 1 May 1965, he was Professor of Graphic Design at Yale University for the last ten years of his life.

11. The book was published in French as Leçons de photographie (2007).

12. Selections from the series were published in different versions subsequently, Shore (2005) being the most comprehensive with 312 images.

13. A selection of 49 photographs was first published as Shore (1982).

14. The images in the 1972 exhibition did not have a frame at all, a commonplace arrangement today but not at all well-received for colour photography at the time.

15. http://www.poleimagehn.com/archives-expositions-centre-photographique/item/walkerevansthe-magazine-work

16. For critical acclaim of this work by Campany, see http://www.brooklynrail.org/2014/07/ art_books/walker-evans-the-magazine-work, http://time.com/3880053/walker-evans-a-rebelrises-at-fortune/ and http://www.theguardian.com/artanddesign/gallery/2014/may/16/walkerevans-magazine-work-in-pictures

17. http://aperture.org/shop/stephen-shore-survey-books 


\section{INDEX}

Keywords: Walker Evans, text and image, documentary style, photo-essay, layout, Stephen Shore, snapshot style, colour photography, Rencontres de la Photographie d'Arles

Subjects: Photography

Mots-clés: Walker Evans, texte et image, style documentaire, essai photographique, mise en page, Stephen Shore, style de l'instantané, photographie en couleur, Rencontres de la Photographie d'Arles

\section{AUTHORS}

\section{DANIEL HUBER}

Maître de conférences

Université de Toulouse

daniel.huber@univ-tlse2.fr 